Tarih Kültür ve Sanat Araştırmaları Dergisi

Revue des Recherches en Histoire Culture et Art

$$
\text { مجلة البحوث التاريخية و الثقافية والفنية }
$$

Vol. 6, No. 5, November 2017

Copyright (C) Karabuk University http://kutaksam.karabuk.edu.tr

\title{
DOI: 10.7596/taksad.v6i5.1310
}

Citation: Bachiev, B., Markaryan, J., Pashtaev, B., Savina, V., Smyshnov, K., Feyzullayev, F., \& Kharchenko, L. (2017). Determinants of Regional University Development in Modern Russia. Journal of History Culture and Art Research, 6(5), 31-36. doi:http://dx.doi.org/10.7596/taksad.v6i5.1310

\section{Determinants of Regional University Development in Modern Russia}

\author{
Bachey A. Bachiev ${ }^{1}$, Julia A. Markaryan ${ }^{2}$, Bulat D. Pashtaev ${ }^{3}$, \\ Veronika I. Savina ${ }^{4}$, Konstantin M. Smyshnov ${ }^{5}$, Fyodor S. Feyzullayev ${ }^{6}$, Leonid N. Kharchenko ${ }^{7}$
}

\begin{abstract}
The article describes the determinants that are manifested in regional social-economic complexes and determine the main trends of development and educational activities for regional universities. The authors determined and characterized such determinants as social-economic (or financial, and infrastructural) uneven development of Russia; the economic mechanism of higher education economic accessibility stratification; the need to equalize the professional educational network in the regions of Russia to ensure the development of the intellectual and professional potential of regions and the gradual equalization of Russia economic development in terms of regional and geographical dimensions; the degree of "openness-closure" concerning a regional university and the development of understanding that a university is a system by its structural and functional organization and, consequently, the subject to the laws of social, ethnic, state and regional morphology of education; an ambiguous (often negative or neutral) attitude of teachers and organizers of higher education to innovations, which creates the contradictions and extends the periods of crisis processes in the educational system of a regional university.
\end{abstract}

Keywords: Higher education, Regional University, University development, Development determinants.

\footnotetext{
${ }^{1}$ Dagestan State Agrarian University Makhatchkala, M.Gadzhieva, 180, Russia. E-mail: Bachey@mail.ru

${ }^{2}$ Don State Technical University Gagarin square 1, Rostov-on-Don, Russia. E-mail: mobilityoffice@mail.ru

${ }^{3}$ Dagestan State Agrarian University Makhatchkala, M. Gadzhieva, 180, Russia. E-mail: bulat-625@mail.ru

${ }^{4}$ Dagestan State Agrarian University Makhatchkala, M. Gadzhieva, 180, Russia. E-mail: Vik45172@mail.ru

${ }^{5}$ North-Caucasus Federal University Pushkin Street, 1, Stavropol, Russia. E-mail: ksmyshnov@mail.ru

${ }^{6}$ Dagestan State Agrarian University Makhatchkala, M. Gadzhieva, 180, Russia. E-mail:

fedor.feyzullaev@mail.ru

${ }^{7}$ North-Caucasus Federal University, Pushkin Street, 1, Stavropol, Russia. E-mail: innov_harchenko@mail.ru
} 


\section{Introduction}

The experience of a number of countries and regions that achieved the economic growth in recent decades shows that economic growth, and social well-being after it, comes only when a priority role in this process is given to the problems of the overall educational level of population and the quality of expert training increase. It is important that qualitative renewal of education is raised by states to the rank of a political national goal (Akinfiyeva, 2006; Chekmareva, 2002; Babaeva et al., 2014).

A purposeful analysis of the scientific literature showed that at present planning of the future and a longterm development strategy based on it, especially as our society undergoes the era of radical changes becomes especially urgent for Russia, including Russian education and science. At the same time, there is intense work on the organic integration of the Russian economy into the world economy, and of Russian universities into the world educational space. This implies the strengthening of production innovative nature and the strengthening of scientific and educational activities, the development of a special innovation sphere with its specific features and subjects. Interest in innovation is great because without the use of innovations it is practically impossible to create competitive products in any industry nowadays, especially to "create" a competitive expert in the university environment (Kirnen, 2004; Christensen, 2004; Christiansen, 2000).

In this regard, a regional university, as an institutional and evolving element of the social and economic complex of a state and a particular region, should be aimed at development, change, renewal and, as a self-developing, self-learning educational system, it is designed to cultivate activity, initiative, develop the creative abilities among teachers and students.

The regional and historical variability of higher education models is even absolutized. So, for example, 0 . Dolzhenko emphasizes that there was no single university in the history of Europe almost during 1000 years. There were prototypes and the kaleidoscope of various educational institutions, however, they have a lot in common: the names of the faculties, studied disciplines and structure. And, nevertheless, such a similarity was largely external and deceptive (2000, p.27). And further the author concludes that nowadays many universities are called universities, but there are a lot of educational institutions of very different kind named as university.

The purpose of this publication is to identify and characterize the determinants that determine the possibility or impossibility of the progressive development among regional higher education institutions and the quality of regional higher education improvement on the basis of theoretical aspects and the practice of the educational activity of higher education institutions analysis in the North Caucasus region of Russia and the reflection of the scientific, managerial and pedagogical experience of this publication authors.

The analysis showed that most universities of the region under study determine the establishment of a university like a regional knowledge-based educational organization as a strategic goal combining staff training, research and development with their subsequent conversion to the social and economic complex of the North Caucasus region of Russia (Chekmareva, 2002; Kharchenko, 2014a; Zritneva et al., 2016).

At the same time, the development of each individual regional university and the achievement of its goals, takes place against the background of the contradictions that developed in the country higher education system. For example, the development of the higher education system in Russia at a given historical moment is accompanied by its large-scale unfolding or winding up, both within individual regions and throughout the country.

Besides, there is a contradictory situation in Russia currently, which consists in the fact that the Russian economy is permanently moving towards liberalization, i.e. denationalization and, at the same time, the 
state is trying to maintain its dominant position in the education system. Moreover, since the state itself, its economy and the education system are in a dynamic state, it gives a dynamic (unstable) character to all institutions of the state (including higher education) (Chekmareva, 2002; Kharchenko \& Panova, 2010; Babaeva et al., 2014).

The researchers (Zimareva, 2009, pp.83-87; Kimberg, 2003, pp.30-34; Filippov, 1980, pp.231) distinguish contradictions that are invariant ones and persist at any changes: historical, political, financial, and others. The leading place among them is occupied by the gap between the emerging and increasing needs of an individual, society and a state (in the context of research, and a region) within an anticipating development of education quality and the ability of the system to satisfy these needs.

In this article, we will understand contradiction as the interaction of opposing tendencies in the development of social phenomena, which are in inner unity and interpenetration at the same time (Gritsanov \& Abtsianko, 2003). We also consider the inconsistency in the development of university systems as a necessary trend, with the stipulation that contradictions tend to accumulate if they are not removed. The fact is that the contradictions that develop in the country, cause the stagnation of education. The contradictory nature of the ongoing reforms in economy and financial sector, supplemented by the contradictory nature of the reforms in the education system, affects their joint genesis and determines a number of determinants that are more apparent in regional social-economic complexes.

\section{Methodology}

The content of the issues discussed within the framework of this article was received by the authors from a variety of sources and processed with the use of content analysis. The content analysis was carried out in the following logic: 1 ) the study of various sources (scientific literature, regulatory legal acts) containing information on the state of the issue under study; 2 ) quantitative and qualitative analysis of texts with the aim of the subsequent meaningful interpretation concerning the revealed contradictions and determinants; 3) the reflection and analysis of the subjective scientific, pedagogical and managerial experience of the authors; 4) the drawing up of a variety of text materials and ideas in the content of the article text (determination of key concepts, the description of the determinants that affect the development of a modern regional university).

\section{Discussion}

One of the determinants that determine the development of regional universities and the regional higher education in general is the social-economic, or financial, and infrastructural unevenness of Russia development, which generated the process of economic space fragmentation. This led to the transport accessibility decrease for the vocational school in Moscow, St. Petersburg, Novosibirsk, Voronezh, Yekaterinburg, Rostov-on-Don, etc. - in the largest educational centers - for young people from the "backwoods" of Russia, especially from rural areas. Sociological measurements show that $90 \%$ of school leavers want to get a professional education in their region (Problems of Education Affordability, 2003, p.155). Let's note additionally that the scientific and scientific-pedagogical personnel potential of Moscow, Moscow region and St. Petersburg is an excessive one, and it is inadequate one in a number of remote regions (Kharchenko, 2014b).

The next determinant is the established economic mechanisms of stratification concerning the economic accessibility of higher education in the form of commercial education, tutoring, numerous forms of applicant preparation for USE passing and the admission to the educational institutions of higher education (providing the elimination of the gap between the quality of graduate preparation in schools 
and the preparation quality standards reflected in the requirements to the preparation of graduates, presented by universities). Concerning the share of education costs rural residents are marked especially (Problems of education affordability, 2003, p.33). In other words, the graduates of rural schools are the most disadvantaged ones in their rights for a higher education. And the regional universities, especially in agrarian regions are called to ensure the equalization of higher education accessibility for the graduates of rural schools in some extent through the network of their branches in rural areas (Subetto et al., 1997).

Another determinant reflects the requirements to equalize the vocational education network across the regions of Russia (Subetto et al., 1997) in order to ensure the development of the intellectual and professional potential of the regions as a gradual equalization factor in Russia economic development according to regional and geographical aspect. This process is accompanied by the diversification of higher education and is considered by us as a general didactic principle of education development, which develops a new pedagogical system of higher education, the typology of educational organizations and the models of regional educational systems.

Apparently, the permanent diversification of educational systems and their regionalization is conditioned by two reasons. On the one hand, it is related with the inability of a state (and some regions) to support the system of higher education adequately. On the other hand, the system of higher education, is not always (and not everywhere) an effective social institution of the state or a region.

There is the possibility of a qualitative assessment application of the educational system of a university in the procedure, as a special subject of regional educational policy, the evaluation methods based on the degree of a studied system "openness-closure" (Prigogine \& Stengers, 1984) and the level of a publicprivate system management development. This is another of the stated determinants. It is known that there are no completely "open" or completely "closed" systems, but, at present time, educational higher school systems are more closed for society than open systems. Therefore, educational policy, like an economic one, must proceed from this principle and the identification of a regional university educational system should begin with the identification of "openness-closure" degree (Kharchenko, 2014a, 2014b).

Such an "identification" will help to answer the following questions: what part of the personnel potential reproduction (in the areas of training and expertise), taking into account the development of a specific region needs, is covered by internal educational resources, and what part is covered by external ones? What trends of educational and educational productive cooperation of a university and regional enterprises should be developed? By the way, the increase of the higher educational system openness to the community will allow to solve the problem of differentiated social quality standards development concerning higher education for different regions of Russia Kharchenko, 2014a).

The next determinant is the development of the understanding that a university is a system by its structural and functional organization and, therefore, it is subject to system-genetic laws (Subetto et al., 1997), namely, the laws of social, national, ethnic, state, regional morphology of education. At the regional level, for example, these laws acquire the sense of compliance with a regional university "morph nature" - that is, the conformity with a social, cultural, national-ethnic, economic "morphology" of a region. The regional university bears a "seal" of this morphological specificity and it is reflected in structures, primarily in the targeted and functional one, the management of external, systematic-social quality of higher education.

As a determinant, we single out an ambiguous (often a negative or a neutral one) attitude of teachers and the organizers of higher education to innovations and modernizations aimed at educational service quality increase, which also creates contradictions and extends the time of crisis processes in the educational system of a regional university (Kharchenko \& Panova, 2010, pp.144-148). 
In this regard, it is necessary to turn to the thoughts by F.G. Coombs, who analyzed the crisis in education (Coombs, 1970, p.128) and suggested that all efforts should be made to put an end to such a situation, when everyone is persistently inspired by the idea that everything new in education will inevitably be of secondary importance.

These words take on a special significance when it comes to new educational technologies, when the prospects of new technology introduction in the educational process of a university are discussed. In fact, it is about whether it is necessary, desirable and possible to change all the technology used in training radically and create a new, unified system of teaching and learning that combines the best that can be taken from the past and the present - a system, capable of giving the best results at each stage of training (Coombs, 1970, p.129).

First of all, such a state of affairs sets the tasks of new theoretical approaches development in the field of innovative management at regional universities, and secondly, in the field of personnel training (the heads of structural units, teachers and the staff of regional universities) for the management of regional universities in the terms of constant changes.

\section{Conclusion}

Thus, proceeding from the information mentioned above, we may conclude that the higher education system is the sphere of constant interaction and the clash of interests concerning a state and society represented by their institutions and citizens, and it fulfills its social and educational functions which are specific in each region.

Rather principal changes in the external environment for the functioning of regional educational organizations of higher education in the form of determinants require an adequate change in external and internal management, the transition to the principles of strategic planning, the educational services market marketing, personnel and innovation management.

The model of a regional university, as a regional science-intensive educational organization organically built into a regional social-economic complex, is in the development phase, which, on the one hand, allows a multidimensional study concerning the issue of such a university model design, and, on the other hand, updates and enhances the theoretical and the practical importance of the problem study concerning the provision of high quality scientific and educational services at a regional university.

\section{References}

Akinfiyeva, N. V. (2006). Social mechanisms of sustainable development management in Russian education. Saratov: Saratov University Publishing House.

Babaeva, E.; Gulyakin, D.; Magomedova, R.; Panova, I.; Pashtaev, B. \& Kharchenko, L. (2014). Russian syndromes, impeding the development of the innovation processes in education. Life Science Journal, $11(9 \mathrm{~s}), 184-187$.

Chekmareva, V. V. (ed.) (2002). Management of social-economic processes in the regions: the role of universities. Kostroma: KSU named after N.A. Nekrasov, 2002.

Christensen, K. (2004). The innovator's dilemma. Trans. from English. Moscow: Alpina Business Books. 
Christiansen, J. A. (2000). Building the innovative organization: Management systems that encourage innovation. New York: St. Martin's Press.

Coombs, F. G. (1970). Crisis of education in modern world (system analysis). Moscow: Progress.

Dolzhenko, O. (2000). Social-cultural preconditions for the development of a new paradigm of higher education. Alma Mater University Bulletin, 10.

Filippov, F. R. (1980). Sociology of education. Moscow: Knowledge.

Gritsanov, A. A. \& Abtsianko V. L. (ed.) (2003). Sociology: encyclopedia. Moscow.

Kharchenko, L. N. (2014a). Scientific and methodological support of educational service quality. Moscow: Direct-Media.

Kharchenko, L. N. (2014b). The concept of the program for university teacher preparation. Moscow: Direct-Media.

Kharchenko, L. N. \& Panova, I. E. (2010). The study of university teacher readiness for the implementation of innovative activities: The world of education - education in the world. Scientific and methodical journal, 1(37), 144-148.

Kimberg, A. N. (2003). Universities: Contradictions of development. University management: practice and analysis, 1(24), 30-34.

Kirnen, M. (2004). Update or die! Trans. from English. St. Petersburg: Krylov.

Petrova, N. P.; Mareev, V. I.; Pivnenko, P. P.; Kotov, S. V.; Kotova, N. S.; Gulyakin, D. V. \& Kharchenko, L. N. (2016). The Higher School Teacher Matrix of Competences. The Social Sciences, 11(18), 4539-4543.

Prigogine, I. \& Stengers, I. (1984). Order out of chaos. Man's new dialogue with nature. London: Heinemann.

Problems of education affordability (2003). The series "Scientific projects of SISP - IISP Working Papers WP3 / 2003/01. Moscow: Independent Institute for Social Policy.

Subetto, A. I.; Volkova, Yu. A. \& Volkova, A. Yu. (1997). Statistical and social-geographic qualimetric monitoring concerning the reproduction of intellectual potential and education in Russia. Moscow: Algol.

Zimareva, T. G. (2009). Diversification of the contradictions concerning the development of higher education in transforming Russia. Bulletin of Chelyabinsk state university, 33(171).

Zritneva, E. I.; Igropulo, I. F.; Klushina, N. P.; Magin, V. A.; Panova, I. E.; Kharchenko, L. N. \& Shapovalov, V. K. (2016). Method to Estimate a Regional IHL (Institution of Higher Learning) Competitiveness. Social Sciences, 11(29), 4539-4543. 